\title{
Imiona poznaniaków u progu XVII stulecia (na materiale Akt squdu wójtowskiego) ${ }^{1}$
}

\section{Wstęp}

Przedmiotem badań przedstawionych $\mathrm{w}$ tym artykule są antroponimy imiennicze mieszkańców Poznania z początku XVII wieku. Zostały one wyekscerpowane z rękopiśmiennego źródła dokumentacyjnego zatytułowanego Acta spectabilis domoni advocati civitatis Posnaniae annorum 1601 et 1602 gesta atque conscripta (Akta sqdu wójtowskiego z lat 1601 i 1602).

Materiał, który zamierzam omówić, stanowią antroponimy uczestników procesu sądowego, oznaczenia identyfikujące strony biorące w nim udział. Taki charakter źródła, jaki kształtował się pod wpływem czynników pozajęzykowych (stosunki społeczne, etniczne, wyznaniowe), odzwierciedla złożone procesy onomastyczne, ukazując wzajemne relacje między nimi.

Archiwalna księga realizuje odmianę języka urzędowo-oficjalnego, ale różnogatunkowego. Identyfikacja osób naruszających prawo i stających przed sądem (jurydyczna kompetencja wójta) wymagała ścisłego określania osób, co odbywało się przede wszystkim w sposób oficjalny (tekst łaciński) oraz w sposób potoczny (zapis zbliżony do języka mówionego; tekst polski). Protokoły rozpraw podkreślają krewkość charakterów dorosłych poznaniaków obojga płci, co znaczy, że kobiety również bywały sądzone i oskarżane o różne przewiny (nieuczciwe interesy, kradzieże, obelgi czy długi).

${ }^{1}$ Niniejszy artykuł realizuje założenia projektu badawczego własnego (grant ministerialny) Nr H01 D 04230 Nazwiska mieszkańców Poznania na tle antroponomastykonu innych miast wielkopolskich i ewolucji polskiego systemu antroponimicznego. Projekt opracowała I. Sarnowska-Giefing. 
Z poznańskiego źródła wyekscerpowałam łącznie 116 różnych imion (jednostek leksykalnych). Zarejestrowałam 88 imion męskich ${ }^{2}$ z 905 użyciami tekstowymi oraz $\mathbf{2 8}$ onimów żeńskich z 304 użyciami.

Imiona, których nosicielami były osoby zamieszkujące Poznań na początku XVII wieku, występowały w dokumencie w dwojakiej postaci: obcej (łacińskiej lub zlatynizowanej) - te formy zapisu przeważają - oraz z cechami przyswojenia do języka polskiego. Postać łacińska obowiązywała w kontaktach oficjalnych i w dokumentach prawnych. Imiona w tej postaci pojawiały się $\mathrm{w}$ formie pełnej oraz w formach słowotwórczo pochodnych, derywowanych. Ponadto analizowane źródło pozwala zaobserwować predylekcję pisarza (Jan Schedell) do latynizacji polskich compositów, por. Dobeslaus, Sventoslaus.

\section{Stan badań}

Badania nad polskim nazewnictwem osobowym prowadzone są w różnych ośrodkach naukowych kraju, jednakże większa część tych prac nie jest poświęcona historycznemu imiennictwu. Na potrzebę takich badań uwagę zwrócił pod koniec lat siedemdziesiątych Henryk Borek, pisząc:

nadawanie imion i związane $\mathrm{z}$ tym zjawiskiem aspekty onomastyczne oraz socjolingwistyczne (charakter nadawanych imion, ich częstość występowania uzależniona od czasu, regionu i wielu innych czynników, zwłaszcza socjolingwistycznych, sposoby skracania imion) powinny być przedmiotem stałego zainteresowania antroponimii, tymczasem nasz dotychczasowy dorobek na tym polu jest więcej niż skromny33.

W ośrodku poznańskim podejmowano próby realizacji owych badań. Dysponujemy bowiem artykułami Tadeusza Skuliny (Najczęstsze chrzestne imiona kobiet w XIV i XV wieku ${ }^{4}$ oraz Imiona kobiet w Wielkopolsce XVII i XVIII wiek $u^{5}$ )

${ }^{2}$ Imiona Jan i Iwan umieściłam w jednym artykule hasłowym. Podobnie postąiłam w przypadku imion Mikołaj i Klaus, Mateusz i Maciej oraz Franciszek i Fr'ntat (forma z abrewiacją). Do ogólnej liczby haseł nie wliczałam wariantów fonetycznych i graficznych analizowanych imion.

${ }^{3}$ H. Borek, U. Szumska, Nazwiska mieszkańców Bytomia od końca XVI wieku do roku 1740, Warszawa-Wrocław 1976, s. 75; H. Borek, Socjolingwistyczne aspekty imiennictwa, „Onomastica" XXIII, 1978, s. 166.

${ }^{4}$ T. Skulina, Najczęstsze chrzestne imiona kobiet w XIV i XV wieku, „Studia Polonistyczne” XIV/XV, 1986/1987.

5 T. Skulina, Imiona kobiet w Wielkopolsce XVII i XVIII wieku, „Slavia Occidentalis” XLV, 1988. 
i pracą Bożeny Mikołajczakowej (Nazwy osobowe w XVII-XIX w. na terenie dawnej ziemi gostyńskiej ${ }^{6}$, a także spostrzeżeniami historyka - Jacka Wiesiołowskiego (Socjotopografia późnośredniowiecznego Poznania ${ }^{7}$ ). Ponadto wyliczyć można co najmniej kilkanaście prac magisterskich powstałych na podstawie wielkopolskich materiałów ${ }^{8}$. W ostatnich zaś czasach odnotować można wzmożone zainteresowanie podniesioną w artykule problematyką ${ }^{9}$.

\section{Cel badań}

Głównym zadaniem tego artykułu jest zbadanie różnych typów imienia osobowego oraz ich analiza leksykalna (ogólny podział na imiona rodzime i obce, a w ich obrębie dalsze klasyfikacje). Celem jest także przedstawienie pochodzenia wyekscerpowanych imion oraz ich miejsca w historycznej antroponimii i kulturze; planuję dodatkowo skupić się na funkcjonowaniu onimów imienniczych w ówczesnym społeczeństwie, a także wskazać tendencje imiennicze, motywy nadawania imion i ich popularność.

${ }^{6}$ Niepublikowana rozprawa doktorska.

7 J. Wiesiołowski, Socjotopografia późnośredniowiecznego Poznania, Poznań 1982.

${ }^{8}$ Por. prace magisterskie napisane pod kierunkiem profesora T. Skuliny: M. Lewandowska, Nazwy osobowe w księdze chrztów Parafii pod wezwaniem Wniebowstapienia Najświętszej Marii Panny w Kościanie z lat 1598-1609; G. Skowrońska, Nazwy osobowe w księdze ślubów Parafi Najświętszej Marii Panny w Śremie w latach 1606-1626; E. Wacławik, Nazwy osobowe w księdze chrztów Parafii Św. Wawrzyńca w Koźminie w latach 1634-1644; M. Józefiak, Nazwy osobowe w księdze parafialnej Pogorzeli z I pot. XVII wieku; B. Ratajczak, Nazwy osobowe w ksiegach parafialnych Dopiewa w XVII wieku.

${ }^{9}$ Por. I. Sarnowska-Giefing, $Z$ antroponomastykonu Poznania. Sposoby identyfikowania kobiet w spisach obywateli miasta z XVI i poczatku XVII wieku, w: Studia Linguistica. In honorem Edvardi Breza, Bydgoszcz 2008, s. 212-220; eadem, Problematyka dialektologiczna w badaniach historycznej antroponimii Poznania, w: Gwary dziś 4. Konteksty dialektologii, red. J. Sierociuk, Poznań 2007, s. 95-104; eadem, Nazwy dawnych altarii poznańskich wobec antroponomastykonu kultury, w: Poznańskie Spotkania Językoznawcze, red. Z. Krążyńska, Z. Zagórski, t. XVI, Poznań 2007, s. 109-117; Kult świętych i błogosławionych (też poznaniaków $i$ Wielkopolan) oraz jego odbicie w poznańskiej antroponimii. Na podstawie najstarszych spisów obywateli Poznania, w: Język, społeczeństwo, wartości, red. E. Laskowska, I. Benenowska, M. Jaracz, Bydgoszcz 2008, s. 389-404; eadem, Imiona mieszkańców Poznania w dobie reformacji i kontrreformacji. Rekonesans badawczy, w: Pamięci Profesora Skuliny w 15. rocznicę śmierci, red. A. Pihan-Kijasowa, I. Sarnowska-Giefing, Poznań 2008, s. 117-143; A. Kulupa, Mieszkańcy Poznania w świetle najstarszej księgi metrykalnej Kolegiaty św. Marii Magdaleny, „Archiwariusz. Biuletyn Archiwum Archidiecezjalnego w Poznaniu” 2007, nr 2. 


\section{Analiza zgromadzonego materiału}

Niniejszy artykuł zawiera przykłady staropolskiego imiennictwa osobowego (6 imion), a także onimy o proweniencji chrześcijańskiej (82 imiona). W przypadku imion o rodowodzie słowiańskim starałam się objaśnić znaczenia leksemów motywujących człony imion złożonych. Imiona chrzestne ujęłam zaś ze stanowiska motywacji religijno-kulturowej. Dążyłam do ujawnienia powodów nadawania owych deskrypcji jednostkowych. Wskazywałam na popularność imion bohaterów Starego Testamentu i Nowego Testamentu oraz kult świętych. Podobnie jak w klasyfikacji użytej do opisu imion żeńskich, tak i tu uwzględniałam pochodzenie językowe omawianych antroponimów.

\section{Imiona pochodzenia słowiańskiego (rodzime)}

Imiona złożone (dwuczłonowe) podaję ze znaczeniem leksemów motywujących człony imion oraz polami znaczeniowymi w obrębie poszczególnych części mowy ${ }^{10}$.

1. Leksemy rzeczownikowe oznaczające:

a) wartości ważne w życiu rodzinnym i społecznym:

ps. *slava 'sława', *slavati 'sławić': Dobiesław', Jarosław, Stanisław, Świętosław, Wacław (por. Więcesław),

ps. *těcha 'uciecha, pociecha': Wojciech,

b) pojęcia związane z walką i wojną:

ps. * vојь 'wojownik': Wojciech.

2. Czasowniki oraz rzeczowniki odsłowne wyrażające:

a) działania związane $\mathrm{z}$ urządzeniem porządku społecznego, z tworzeniem przestrzeni oswojonej:

ps. *stati 'stać': Stanistaw.

3. Leksemy przymiotnikowe oznaczające:

a) cechy ogólnie pozytywne, wartościujące dodatnio:

ps. *vętjъ 'większy': Wacław (por. Więcesław),

b) przymioty przywódcy, wojownika:

ps. *dobъ, dobь 'stosowny, zdatny', scs. dobljъ 'dzielny': Dobiestaw,

ps. *jarb 'surowy, ostry': Jarostaw,

ps. *svętъ 'święty, mocny': Świętosław.

10 Por. M. Malec, Imiona chrześcijańskie w średniowiecznej Polsce, Kraków 1994.

11 Większość antroponimów imienniczych wystapiła w źródle w obocznych wariantach fonetycznych albo też w postaci łacińskiej. Na potrzeby artykułu używam literackich form imion. 
Człon drugi staropolskich męskich imion złożonych jest monosylabiczny, z reguły to nazwa abstraktu. Człon pierwszy bywa dwusylabiczny (zakończony samogłoską) i dążący do skrócenia lub monosylabiczny.

$\mathrm{W}$ analizowanym przeze mnie materiale staropolskich imion dwuczłonowych dominują leksemy przymiotnikowe. Nie ma poświadczeń z członem liczebnikowym, przysłówkowym czy zaimkowym. Nie wyekscerpowałam także archaizmów i neologizmów leksykalnych. Podobnie ma się rzecz z imionami jednotematowymi.

\section{Imiona zapożyczone - chrześcijańskie}

I. Imiona biblijne - (hebrajskie, aramejskie, greckie, łacińskie)

1. Imiona motywowane przez męskie postaci ze Starego Testamentu (18 imion):

hebr.: Aaron, Abraham, Adam, Daniel, Dawid, Eliasz, Gabriel, Izaak, Izrael, Jakub (też NT), Jermiasz, Józef (też NT), Michat, Mojżesz, Salomon, Samuel, Tobiasz, Zachariasz.

2. Imiona motywowane przez postaci występujące w Ewangelii oraz w Dziejach Apostolskich i w Listach Apostolskich (NT):

a) pochodzenia semickiego - hebrajskie i aramejskie (10 imion): Bartłomiej, Jakub (też ST), Jan, Łazarz, Mateusz-Maciej, Natanael, Józef (też ST), Szymon, Tomasz, Zachariasz (też ST); odpowiedniki wsł.: Iwan; polskie spieszczenie: Janusz.

b) pochodzenia greckiego (4 imiona): Andrzej, Nikodem, Piotr, Stefan,

c) pochodzenia łacińskiego i łacińsko-greckiego (3 imiona): Łukasz, Marek, Pawet.

3. Imiona związane $\mathrm{z}$ Biblią przez tradycję i legendę oraz imiona od nazw przywołujących osoby i wydarzenia biblijne (4 imiona): Joachim (hebr.), $\mathrm{Ka}$ sper (pers.), Melchior (hebr.), Baltazar (babil.).

\section{Imiona motywowane przez świętych}

1. Imiona motywowane pierwotnie przez świętych okresu starochrześcijańskiego:

a) pochodzenia greckiego (9 imion): Aleksander, Ambroży, Erazm, Grzegorz, Hieronim, Jerzy, Krzysztof, Mikołaj, Prokop (też 2a),

b) pochodzenia łacińskiego (16 imion): Adrian, Antoni (też 2b), Augustyn, Błażej, Fabian, Feliks, Klemens, Laurenty, Marcin, Marian, Sebastian, Seweryn, Urban, Walenty, Walery, Wincenty.

2. Imiona motywowane przez świętych średniowiecza (VI-XV wiek):

a) pochodzenia greckiego (1 imię): Prokop (też 1a),

b) pochodzenia łacińskiego (3 imiona): Antoni (też 1b), Benedykt, Franciszek,

c) pochodzenia prawdopodobnie celtyckiego (2 imiona): Gawet, Kilian, 
d) pochodzenia germańskiego (13 imion): Albert, Arnold, Bernard, Engelbert, Fryderyk, Henryk, Herman, Konrad, Leonard, Ludwik, Ulryk, Wolfgang, Zygmunt,

e) pochodzenia słowiańskiego (6 imion): Dobiesław, Jarosław, Stanisław, Świętosław, Wacław, Wojciech.

W zakresie imion żeńskich $\mathrm{w}$ artykule zgromadziłam jedynie formy antroponimów pochodzenia chrześcijańskiego ${ }^{12}$ (28 imion) używanych przez mieszkanki Poznania z początku XVII wieku. Imiona chrzestne wyodrębniłam ze zbioru nazw osobowych przez wykrycie i identyfikację motywacji religijnej. W tym przypadku jedynej, która rządziła procesem nominacyjnym. Przejawia się ona w nadawaniu imion ze względu na patronat świętych, cześć żywioną dla postaci biblijnych oraz ich obecność w liturgii Kościoła.

Klasyfikacja przedstawia się następująco:

I. Imiona biblijne - reprezentowane przez imiona kobiecych postaci z Biblii (hebrajskie i aramejskie)

1. Imiona motywowane przez kobiece postaci ze Starego Testamentu (3 imiona):

hebr.: Anna (zob. 1.3), Ewa, Zuzanna.

2. Imiona motywowane przez kobiece postaci $\mathrm{z}$ Nowego Testamentu (4 imiona):

hebr. i aram.: Elżbieta, Magdalena, Marta, Maryja.

3. Imię związane z Biblią przez tradycję (1 imię):

hebr.: Anna (zob. 1.1).

\section{Imiona motywowane przez święte}

1. Imiona motywowane przez święte okresu starochrześcijańskiego:

a) pochodzenia greckiego (10 imion): Agnieszka, Anastazja, Apolonia, Barbara, Dorota, Eufemija, Helena, Katarzyna, Matgorzata, Zofia,

b) pochodzenia łacińskiego (6 imion): Emerencyjana, Justyna, Krystyna, Eucja, Regina, Urszula.

Imiona chrzestne motywowane przez imiona kobiecych postaci biblijnych i przez święte okresu starochrześcijańskiego mogą być później motywowane przez święte okresu następnego, np. Elżbieta przez biblijną Elżbiete (NT), a następnie przez sławne święte z XIII i XIV w., Elżbietę z Turyngii i Elżbietę Węgierską̨ ${ }^{13}$.

2. Imiona motywowane przez święte okresu średniowiecza:

a) pochodzenia łacińskiego (1 imię): Róża,

b) pochodzenia germańskiego (2 imiona): Gertruda, Jadwiga.

${ }^{12}$ Nie wyekscerpowałam z dostępnego mi materiału źródłowego żadnego onimu feminatywnego, który reprezentowałby grupę imion rodzimych, słowiańskich.

${ }^{13}$ M. Malec, op.cit., s. 23. 


\section{Imiona żeńskie utworzone od męskich}

1. Imiona motywowane przez imiona męskich postaci ze ST i NT (1 imię): Bartosza.

2. Imiona motywowane przez imiona męskich świętych starochrześcijańskich: pochodzenia łacińskiego (1 imię): Sabina.

\section{Listy frekwencyjne $i$ rangowe imion ${ }^{14}$}

\begin{tabular}{|c|c|c|c|c|c|}
\hline Ranga & Imię męskie & Frekwencja & Ranga & Imię męskie & Frekwencja \\
\hline 1 & $\begin{array}{l}\text { Jan } \\
\text { Iwan }\end{array}$ & $\begin{array}{r}123 \\
2\end{array}$ & 25 & Sebastian & 9 \\
\hline 2 & Marcin & 56 & 26 & Stefan & 9 \\
\hline 3 & Mateusz & 50 & 27 & Abraham & 8 \\
\hline 4 & Albert & 48 & 28 & Błażej & 7 \\
\hline 5 & Jakub & 43 & 29 & Gabriel & 7 \\
\hline 6 & Andrzej & 42 & 30 & Mojżesz & 7 \\
\hline 7 & Stanisław & 41 & 31 & Baltazar & 6 \\
\hline 8 & Jerzy & 30 & 32 & Henryk & 6 \\
\hline 9 & Grzegorz & 27 & 33 & Melchior & 6 \\
\hline 10 & Łukasz & 24 & 34 & Zygmunt & 6 \\
\hline 11 & Piotr & 24 & 35 & Aleksander & 5 \\
\hline 12 & Kasper & 23 & 36 & Dawid & 5 \\
\hline 13 & Pawel & 23 & 37 & Fryderyk & 5 \\
\hline 14 & Bartłomiej & 21 & 38 & Hieronim & 5 \\
\hline 15 & Krzysztof & 21 & 39 & Konrad & 5 \\
\hline 16 & Szymon & 20 & 40 & Salomon & 5 \\
\hline 17 & Laurenty & 18 & 41 & $\begin{array}{l}\text { Franciszek } \\
\text { (w tym Frącek) }\end{array}$ & 5 \\
\hline 18 & Mikołaj, Klaus & 18 & 42 & Walery & 4 \\
\hline 19 & Walenty & 17 & 43 & Benedykt & 3 \\
\hline 20 & Adam & 16 & 44 & Daniel & 3 \\
\hline 21 & Michał & 15 & 45 & Jarosław & 3 \\
\hline 22 & Tomasz & 10 & 46 & Józef & 3 \\
\hline 23 & Zachariasz & 10 & 47 & Samuel & 3 \\
\hline 24 & Marek & 9 & 48 & Urban & 3 \\
\hline
\end{tabular}

${ }^{14}$ Listy pokazują rozkład frekwencji wszystkich antroponimów imienniczych wyekscerpowanych ze źródła (oznaczają łącznie 1209 denotatów). 


\begin{tabular}{|c|c|c|c|c|c|}
\hline Ranga & Imię męskie & Frekwencja & Ranga & Imię męskie & Frekwencja \\
\hline 49 & Wacław & 3 & 69 & Fabian & 1 \\
\hline 50 & Hertwik & 2 & 70 & Feliks & 1 \\
\hline 51 & Izaak & 2 & 71 & Gaweł & 1 \\
\hline 52 & Janusz & 2 & 72 & Herman & 1 \\
\hline 53 & Joachim & 2 & 73 & Iohelis & 1 \\
\hline 54 & Łazarz & 2 & 74 & Izrael & 1 \\
\hline 55 & Seweryn & 2 & 75 & Jeremiasz & 1 \\
\hline 56 & Wincenty & 2 & 76 & Kilian & 1 \\
\hline 57 & Aaron & 1 & 77 & Klemens & 1 \\
\hline 58 & Abdula & 1 & 78 & Leonard & 1 \\
\hline 59 & Adrian & 1 & 79 & Ludwik & 1 \\
\hline 60 & Ambroży & 1 & 80 & Marian & 1 \\
\hline 61 & Antoni & 1 & 81 & Natanael & 1 \\
\hline 62 & Arnold & 1 & 82 & Nikodem & 1 \\
\hline 63 & Augustyn & 1 & 83 & Prokop & 1 \\
\hline 64 & Bernard & 1 & 84 & Świętosław & 1 \\
\hline 65 & Dobiesław & 1 & 85 & Tobiasz & 1 \\
\hline 66 & Eliasz & 1 & 86 & Ulryk & 1 \\
\hline 67 & Engelbert & 1 & 87 & Wojciech & 1 \\
\hline 68 & Erazm & 1 & 88 & Wolfgang & 1 \\
\hline
\end{tabular}

\begin{tabular}{|l|l|l||l|l|l|}
\hline Ranga & Imię żeńskie & Frekwencja & Ranga & Imię żeńskie & Frekwencja \\
\hline 1 & Anna & 52 & 15 & Gertruda & 4 \\
\hline 2 & Regina & 33 & 16 & Helena & 4 \\
\hline 3 & Agnieszka & 27 & 17 & Urszula & 3 \\
\hline 4 & Jadwiga & 25 & 18 & Justyna & 2 \\
\hline 5 & Katarzyna & 25 & 19 & Anastazja & 1 \\
\hline 6 & Zofia & 23 & 20 & Bartłomieja & 1 \\
\hline 7 & Elżbieta & 21 & 21 & Emerencjana & 1 \\
\hline 8 & Małgorzata & 18 & 22 & Eufemia & 1 \\
\hline 9 & Barbara & 16 & 23 & Krystyna & 1 \\
\hline 10 & Ewa & 15 & 24 & Maria & 1 \\
\hline 11 & Dorota & 8 & 25 & Marta & 1 \\
\hline 12 & Magdalena & 7 & 26 & Róża & 1 \\
\hline 13 & Lucja & 6 & 27 & Sabina & 1 \\
\hline 14 & Apolonia & 4 & 28 & Zuzanna & 1 \\
\hline
\end{tabular}




\section{Jednoimienność}

Generalną zasadą nominacji w analizowanym źródle jest jednoimienność. Wyekscerpowane przeze mnie imiona w znacznej liczbie występowały jako jeden ze składników zestawienia antroponimicznego. Rzadko pojawiały się jako jedyne onimiczne określenie osoby. W tekstach źródłowych imię w swej nadrzędnej funkcji występowało $\mathrm{w}$ zestawieniu $\mathrm{z}$ innym określeniem $\mathrm{z}$ reguły na pierwszym miejscu. Jeśli znalazło się na drugiej pozycji, to znaczy, że pełniło inną funkcję, np. nazwiskotwórczą (por. Laurentinus Augustyn; Caspari Ulrych; Ioannis Urban).

\section{Imiona popularne, imiona modne $e^{15}$}

W omawianym okresie najczęściej nadawane i powszechnie używane były imiona ogólnochrześcijańskie. Procent imion staropolskich jest znikomy (w całym zbiorze zarejestrowałam jedynie sześć takich antroponimów imienniczych). Zaliczam do nich onimy Stanisław i Wojciech, bo chociaż weszły one do kalendarza chrześcijańskiego i były noszone przez patronów naszego kraju, czynnikiem rozstrzygającym o zastosowanej klasyfikacji jest geneza owych antroponimów.

Poniżej przedstawiam zestawienia najpopularniejszych męskich imion słowiańskich i chrześcijańskich wyekscerpowanych z badanego materiału źródłowego wraz z sumą ich użyć:

$\begin{array}{ll}\text { imiona przedchrześcijańskie } & \text { imiona chrześcijańskie } \\ \text { Stanisław }-41 & \text { Jan }-123 \\ \text { Jarosław }-3 & \text { Marcin }-56 \\ \text { Wacław }-3 & \text { Mateusz }-50 \\ \text { Dobiesław }-1 & \text { Albert }-48 \\ \text { Świętosław }-1 & \text { Jakub }-43 \\ \text { Wojciech }-1 & \text { Andrzej }-42 \\ & \text { Jerzy }-30\end{array}$

${ }^{15}$ Imię może być popularne, ale już niemodne oraz modne, ale jeszcze niepopularne. Kryterium mody nie jest bowiem częstość występowania imienia, lecz częstość jego nadawania. Por. J. Jaroszuk, Imiona chrzestne w parafii Białystok (XVIII wiek), w: Warsztat wspótczesnego onomasty, red. D. Kopertowska, Kielce 1983, s. 68. 
W porównaniu z onimami męskimi imiona Wielkopolanek - mieszkanek Poznania miały proweniencję tylko chrześcijańską. Najpopularniejszymi były następujące antroponimy feminatywne:

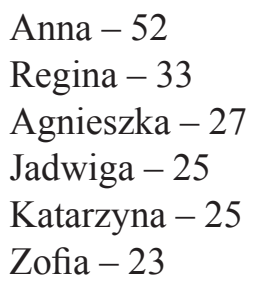

Pięć spośród tych imion (wyłączywszy onim Regina) ma dokumentacje z XII i XIII wieku, co wskazywać może na zasadniczo niezmienny repertuar imion będących w użyciu do końca XVI wieku.

Aby wskazać na ciagłość tradycji nazewniczej i wykazać, że imiona motywowane przez świętych stanowiły od wieków zasadniczy zrąb antroponimów będących w użyciu, odwołam się do ustaleń Jacka Wiesiołowskiego układem odniesienia będą imiona wyekscerpowane przez niego z zasobów wian od $1440 \mathrm{roku}^{16}$. Do badań nad imiennictwem kobiecym wykorzystuję dodatkowo materiał zebrany z ksiag parafialnych Wielkopolski a opracowany przez Tadeusza Skulinę ${ }^{17}$. W kontekście tych badań umieszczę zgromadzone przez siebie dane, będące ilustracją zjawiska mody imienniczej początku XVII wieku i potwierdzające wejście imion chrześcijańskich do narodowego onomastykonu.

W połowie XV wieku popularne w Poznaniu były imiona ${ }^{18}$ Jan, Maciej, Andrzej, Mikołaj, Jakub, Marcin, Pawet i Grzegorz. Do imion rzadszych zalicza się onimy: Szymon, Filip, Tomasz, Benedykt, Wawrzyniec, Stefan, Wincenty, Bartosz, Błazej. Przez nowych kupieckich przybyszów wniesione zostały do Poznania imiona Antoni, Ulryk, Henryk, Konrad i Kilian. W końcu XV wieku zanikały też imiona słowiańskie.

Wycinkowość badania powoduje, iż zawodzą próby powiązania cech charakterystycznych kultu świętych z grupami zamożności. Jeżeli to zjawisko występowało

${ }^{16}$ J. Wiesiołowski, op.cit.

${ }_{17}$ T. Skulina, Najczęstsze chrzestne imiona kobiet w XIV i XV wieku; idem, Imiona kobiet w Wielkopolsce XVII i XVIII wieku.

$18 \mathrm{~J}$. Wiesiołowski słusznie zauważa, że imiona występujące w formach narodowych (Bieniasz, Fracek) mogą znamionować ludzi uboższych w grupie noszącej dane imię. 
wśród imion męskich, to ulegało ono zamazaniu w wyniku mobilności społecznej. Nie można też stwierdzić związku między zawodami a używanymi imionami ${ }^{19}$.

Porównując dane z XV wieku z zebranym przeze mnie materiałem, należy podkreślić trwałość tradycji imienniczej.

\section{połowa XV wieku}

1. Jan

2. Mikołaj

3. Maciej

4. Andrzej

5. Jakub

6. Piotr

7. Stanisław

8. Michał

9. Marcin

10. Wojciech koniec XV wieku

1. Maciej

2. Jan

3. Marcin

4. Mikołaj

5. Wojciech

6. Stanisław

7. Piotr

8. Paweł

9. Andrzej

10. Grzegorz

\section{początek XVII wieku}

1. Jan

2. Marcin

3. Mateusz

4. Albert

5. Jakub

6. Andrzej

7. Stanisław

8. Jerzy

9. Grzegorz

10. Łukasz; Piotr

Z dziesięciu najczęstszych imion początku XVII wieku aż dziewięć występuje w rejestrach wcześniejszych (prócz imienia Albert). Zmieniła się jednak kolejność na liście. W stosunku do połowy XV wieku dużą przewagę zyskało imię Jan, awansowało też imię Marcin. Do górnej strefy listy rangowej przeszło imię Łukasz.

Rzadkie i wyjątkowe imiona męskie również mają tradycje średniowieczne. Onimy Ambroży, Antoni, Bernard, Fabian, Kilian, Klemens, Ulryk w zapisach wian są notowane pojedynczo, podobnie jak w źródle z XVII wieku. Za pewną niespodziankę należy uznać pojawienie się w Aktach sqdu wójtowskiego egzotycznego imienia Abdullah. Innowacją są imiona Engelbert i Wolffgang oraz słowiańskie Świętosław. Dziwić może nadzwyczaj rzadkie (jednokrotne) użycie imienia Wojciech.

W odróżnieniu od mężczyzn kobiety notowane w źródle w większości pochodziły z Poznania, dlatego zasób ich imion i frekwencja występowania były bardziej zbliżone do stosunków rzeczywistych. Już w połowie XV wieku najpopularniejsze były imiona Katarzyna, Matgorzata, Jadwiga i Barbara. Z onimów rzadziej używanych wymienić należy imiona Zofia, Regina, Eufemia.

Do porównania niech posłuży poniższe zestawienie:

\footnotetext{
19 J. Wiesiołowski, op.cit., s. 109-110.
} 


\section{XIV-XV wiek}

1. Katarzyna

2. Anna

3. Małgorzata

4. Dorota

5. Barbara

6. Elżbieta

7. Jadwiga

8. Agnieszka

9. Helena

10. Zofia

\section{początek XVII wieku}

1. Anna

2. Regina

3. Agnieszka

4. Jadwiga, Katarzyna

5. Zofia

6. Elżbieta

7. Małgorzata

8. Barbara

9. Ewa

10. Dorota

\section{połowa XVII wieku}

\author{
1. Anna
}

2. Jadwiga

3. Zofia

4. Regina

5. Małgorzata

6. Katarzyna

7. Dorota

8. Agnieszka

9. Elżbieta

10. Ewa

Punktem wyjścia uczyniłam imiona XIV i XV wieku (poświadczone w Słowniku staropolskich nazw osobowych), ponieważ wówczas ukształtował się podstawowy trzon imion (żeńskich). Ponownie uwagę zwraca niezmienność, trwałość i powszechność repertuaru imion używanych przez wieki w Polsce do nominacji. Najczęstsze imiona średniowiecza utrzymały się bowiem w pierwszej dziesiątce do XVII wieku. Kolejność antroponimów na liście zmieniła się. Przewagę zyskało imię Anna, do górnej strefy listy rangowej przeszły także imiona Jadwiga i Zofia. Pojawiło się także rzadkie wcześniej imię Ewa. Pozostałe przetasowania są nieznaczne. Nadal nie pojawiają się antroponimy słowiańskie, zatem nie obserwuje się zasadniczych zmian.

Jeśli chodzi o imiona rzadkie to 8 (Anastazja, Emerencjana, Eufemia, Krystyna, Maria, Marta, Róża, Zuzanna) ma w Polsce tradycję średniowieczną.

Dużą popularność niektórych wyekscerpowanych przeze mnie antroponimów tłumaczyć można żywym kultem świętych, np. Anna - matka Najświętszej Marii Panny, Agnieszka - rzymska męczennica z IV wieku lub Agnieszka z Asyżu, Jadwiga - królowa (zm. 1399), Katarzyna - Sieneńska (zm. 1380) lub Katarzyna Ricci (zm. 1589), Zofia - męczennica rzymska, Elżbieta - matka św. Jana Chrzciciela.

Podstawowy zasób poznańskich imion chrzestnych początku XVII wieku został zaadaptowany już w średniowieczu i przetrwał do naszych czasów. To zasób trwały, podkreślający chrześcijański uniwersalizm i mało podatny na zmiany. W świetle badanego materiału kilkuwiekowe tendencje imiennicze nie były zachwiane prądami innowacyjnymi ${ }^{20}$.

${ }^{20}$ Imiona najczęściej nadawane poznaniakom należą do tych, które modne były w badanym okresie niemal w całej Polsce. Por. H. Borek, U. Szumska, op.cit.; D. Kopertowska, Kieleckie antroponimy XVI i XVII wieku, Kielce 1980; J. Jaroszuk, op.cit.; J. Bystroń, Ksiega imion w Polsce używanych, Warszawa 1938; E. Klisiewicz, Męskie imiona chrzestne w parafii Rudawa koło Krakowa z lat 1570-1897 (na podstawie ksiag metrykalnych), „Onomastica” XXXIII, 


\section{Motywacja}

Motywy wyboru nie są czymś stałym, również w imiennictwie osobowym podlegają one zmianom. Są to zmiany dość powolne, a wywołujące je czynniki - różne: od drobnych, lokalnych o mniejszym lub większym zasięgu do ogólnonarodowych czy nawet ponadnarodowych, internacjonalnych. W zakresie imiennictwa dotyczy to takich zagadnień, jak: zasób nadawanych imion, jego bogactwo lub ubóstwo, motywacje powodujące popularność jednych imion, a odrzucanie innych, przyczyny dużej żywotności albo rzadkości takich czy innych imion ${ }^{21}$.

W analizowanym materiale ze względu na rodzaj źródła trudno było odnaleźć te elementy, które przyjęło nazywać się tradycją ludową, pokoleniową, związaną z motywacją przedchrześcijańską. Chociaż nasycenie badanego tekstu imionami jest duże, to brak w nim zapisów, które pozwalałyby wnioskować o dziedziczeniu imion, ich powtarzaniu w obrębie danej rodziny. Zgromadzone ekscerpty pozwalająjednak ustalić, że najistotniejsza w owym czasie była motywacja religijna (zarówno biblijna, jak i związana z kultem świętego patrona). Szczegóły zamieściłam w poniższym wykazie:

\begin{tabular}{l|c|c|c}
\multicolumn{1}{c|}{ Motywacja religijna } & Imiona męskie & Imiona żeńskie & Razem \\
\hline biblijna & 37 & 25 & 62 \\
\hline przez wzór świętego patrona & 48 & 3 & 51
\end{tabular}

Nie ustaliłam motywacji nadania imion: Abdullah i Johelis.

W ogólnym zestawieniu prymarna okazała się motywacja biblijna. Także wśród onimów żeńskich ma ona znaczną przewagę nad drugim typem motywacji. Nieco inaczej przedstawiają się wyniki dla antroponimów męskich. Ta różnica nie jest zasadnicza, jednak motywacja przez wzór świętego patrona była częstsza.

W analizowanym materiale popularne imiona biblijne to Piotr, Pawet oraz Anna, Magdalena. Dodatkowym powodem nadawania tych onimów było zapewne istnienie $\mathrm{w}$ mieście otoczonym murami i w najbliższej jego okolicy patrociniów, czyli kościołów i kaplic pod wezwaniem ${ }^{22}$ postaci biblijnych, np.

1989; M. Kamińska, Nazwy osobowe w najstarszych księgach metrykalnych parafii Łask, „Onomastica" XXX, 1986; J. Szuta, Z problemów imiennictwa parafi Jeleńcz w powiecie tucholskim od końca XVI do poczqtku XIX wieku (na podstawie ksiag metrykalnych), w: Nazewnictwo na pograniczach, red. J. Ignatowicz-Skowrońska, Szczecin 2005.

${ }_{21}$ D. Kopertowska, Ewolucja motywacji w imiennictwie, „Język Polski” 1994, nr 1, s. 22.

${ }^{22}$ Zwyczaj nadawania kościołom wezwań utrwalił się w praktyce około IV wieku. Początkowo świątynie dedykowano Chrystusowi lub Jego Matce, potem pojawiały się wezwania 
kościół katedralny pod wezwaniem świętych Piotra i Pawła, kolegiata św. Marii Magdaleny (istniejąca od 1263 roku) czy kościół św. Anny (pochodzący z 1480 roku, mieścił się obok kościoła bernardyńskiego). Były to patrocinia związane z kultem patronalnym ${ }^{23}$.

Kościoły nosiły także imiona świętych męczenników, apostołów czy wyznawców. Święta patronalne wprowadzały ich kult w tradycję lokalną. Patrocinia były ważnym elementem więzi międzyludzkich, wyznaczały kościołom miejsce w tworzeniu obyczajów i wydarzeń społecznie ważnych, np. pielgrzymek, jarmarków odpustowych, sądów, wesel i biesiad. Były trwałym elementem krajobrazu kulturowego. W badanych źródłach taką dodatkową motywację należy wskazać dla imion: Jan (kościół św. Jana Jerozolimskiego za Śródką), Marcin (kościół św. Marcina z 1240 roku), Stanisław (kościół św. Stanisława z 1518 roku, mieszczący się w gmachach pojezuickich), Mikołaj (kościół św. Mikołaja z 1142 roku na Zagórzu), Wawrzyniec (kościół św. Wawrzyńca na Chwaliszewie), Małgorzata (kościół św. Małgorzaty na Śródce z 1244 roku), Barbara (kościół św. Barbary na Chwaliszewie z 1453 roku) czy Gertruda (kościół św. Gertrudy z 1456 roku).

Ustalenie motywów decydujących o popularności omawianych imion poznaniaków to zadanie trudne $\mathrm{z}$ powodu braku informacji natury socjolingwistycznej $^{24}$ (poświadczenia onimów wyekscerpowałam z sądowych ksiąg miejskich, w których notowano sprawy obywateli wywodzących się z różnych stanów społecznych, zatem odtworzenie tendencji imienniczych w obrębie poszczególnych grup społecznych nie było możliwe). Udało mi się jednak w analizowanym materiale odnaleźć motywacje związane z wartościami wyrażanymi przez treści imion staropolskich oraz motywacje religijne (wzory świętych ${ }^{25}$ ). Kulturowy czynnik stawał się zatem decydującym w doborze imion chrzestnych. Przekonana jestem, że kierowania się określonym wzorem osobowym w nadawaniu imion wykluczyć nie można. Zapewne należy też wspomnieć tu o motywacji estetycznej. Wydaje się, że imiona najpopularniejsze traktowano jako dobre, ładne, właściwe. Owe „eleganckie” imiona wybierać mogli dla swych dzieci rodzice z niższych warstw społecznych. Odczytywać to należy

apostołów i pierwszych męczenników. Por. A. Witkowska, Titulus ecclesiae. Wezwania wspótczesnych kościołów katedralnych w Polsce, Warszawa 1999, s. 49. Tytuły, dedykacje poznańskich świątyń przytaczam za J. Łukaszewiczem, Obraz historyczno-statystyczny miasta Poznania $w$ dawniejszych czasach, t. 2, Poznań 1998. Por. I. Sarnowska-Giefing, Nazwy dawnych altarii poznańskich...

${ }^{23}$ Patrocinium to drugi człon (tzw. odróżniający) nazwy własnej obiektu kościelnego.

${ }^{24}$ Ów niedostatek sprawił, że nie mogę zająć stanowiska w kwestii socjalnego zróżnicowania mody imienniczej i jej uwarunkowań środowiskowych.

${ }^{25}$ Kościół rozpowszechniał kult określonych świętych, którzy mieli służyć za wzory dla wiernych. 
jako próbę zmiany rzeczywistości pozajęzykowej. Uważano bowiem, że odpowiednio wybrane imię zapewni powodzenie w życiu. Oprócz imienia Maria nie spotkałam się z onimami zastrzeżonymi zwyczajowo.

W sferze domysłów pozostaje ustalenie wpływu tradycji rodzinnej na zasób imion powszechnie w owych czasach używanych, trudno też wskazać konkretne przykłady wpływu księży udzielających chrztu na wybór imienia (szczególny przypadek stanowi nominacja imieniem patrona kościoła, w którym dziecku udziela się sakramentu).

\section{Wnioski}

Rozważania dotyczące problematyki historycznego imiennictwa mieszkańców Poznania na początku XVII wieku - choć są zaledwie wprowadzeniem - wydają się zbieżne z obserwacjami systemu imienniczego prowadzonymi w innych regionach naszego $\mathrm{kraju}^{26}$.

Poznańskie imiennictwo badanego okresu cechuje jednoimienność (występowanie tylko jednego imienia) nawet pośród przedstawicieli wyższych klas społecznych.

W badanym materiale na popularność imion wpływ miały religia oraz tradycja historyczno-kulturowa, w nieco mniejszym stopniu moda - obyczaj przejściowy i zmienny. Imiona dorosłych mieszkańców miasta należą do ogólnochrześcijańskiego systemu imienniczego; imiona słowiańskie używane są sporadycznie. Uzasadnieniem owych religijnych uwarunkowań onimii poznańskiej jest z pewnością zalecenie nadawania na chrzcie imion świętych patronów wydane podczas zakończonego w 1563 roku soboru trydenckiego.

Analizowany system imienniczy ukazuje dużą powtarzalność imion (zwłaszcza męskich).

Motywacja nadania imienia jest typowa dla ówczesnego okresu. Imię jest przeważnie zaczerpnięte z repertuaru (zasobu) onimów biblijnych, zwłaszcza strarotestamentowych ${ }^{27}$. Może być też wynikiem rozpowszechniającego się kultu świętych patronów (wpływ kontrreformacji).

Imiona spełniały w badanym okresie swą prymarną funkcję identyfikacyjną, dyferencjacyjną i nominacyjną. Ich zadaniem było reprezentowanie i od-

26 Por. przypis 20.

27 Wolno zakładać, że jest to jeden ze skutków reformacji, która w planie antroponimicznym implikowała negację kultu świętych i skutkowała zaleceniami używania jedynie imion biblijnych. W 1546 roku wydano dekret zabraniający nadawania imion innych niż biblijne. Por. I. Sarnowska-Giefing, Imiona mieszkańców Poznania $w$ dobie reformacji i kontrreformacji..., s. 128 . 
różnianie członków miejskiej społeczności, a także umożliwienie wzajemnych kontaktów. Identyfikacja przez imię była uzupełniana innymi deskrypcjami określeniami odmiejscowymi, patronimicznymi czy odzawodowymi (tzw. nazwisko historyczne). Imiona pojawiały się na pierwszym miejscu zestawienia antroponimicznego. Honorowanie tej zasady ułatwiało odróżnianie ich od nazwisk w wypadku, gdy nazwisko było równe imieniu.

Oprócz funkcji referencjalnej imię pełniło w badanym okresie także funkcję reprezentowania osoby w społeczeństwie oraz przywoływania genezy, proweniencji danego onimu.

Antroponimy imiennicze zgromadzone w Aktach sq̨du wójtowskiego mają znamiona zbioru tradycyjnego. Niestety, ze względu na charakter źródła nie można prześledzić ewolucji form (np. derywaty, zdrobnienia, spieszczenia) oraz procesu dziedziczenia onimów imienniczych.

\section{Kinga Banderowicz}

\section{The Names of the Inhabitants of Poznan at the Beginning of the 17th Century (based on Akta sadu wójtowskiego)}

The subject matter of the studies presented in the article are the names of Poznan inhabitants from the beginning of the 17th century, excerpted from a manuscriptal source. The courtly records Akta sqqu wójtowskiego present the official and formal variety of the language and consist of the records of court trials.

The onyms confirmed in the source render the description of the then name system feasible. It was characterised by the choice of one name, the origin from the Christian antrophonomasticon, the attachment to the onomatologic tradition as well as great popularity of the most fashionable names. 